\title{
Piplartine induces caspase-mediated apoptosis in PC-3 human prostate cancer cells
}

\author{
EUN-HEE KONG ${ }^{3 *}$, YUN-JIN KIM ${ }^{4 *}$, YOUNG-JIN KIM ${ }^{1}$, HYO-JIN CHO $^{1}$, SUN-NYOUNG YU ${ }^{1}$, \\ KWANG-YOUN KIM ${ }^{1}$, JEONG-HYUN CHANG ${ }^{5}$ and SOON-CHEOL AHN ${ }^{1,2}$
}

\begin{abstract}
${ }^{1}$ Department of Microbiology and Immunology, Pusan National University School of Medicine; ${ }^{2}$ Medical Research Institute, Pusan National University, Busan 602-739; ${ }^{3}$ Department of Family Medicine, Kosin University Gospel Hospital, Busan 602-702; ${ }^{4}$ Department of Family Medicine, Pusan National University School of Medicine, Busan 602-739;

${ }^{5}$ Department of Clinical Laboratory Science, Catholic University of Pusan, Busan 609-757, Korea
\end{abstract}

Received April 16, 2008; Accepted June 23, 2008

DOI: $10.3892 /$ or_00000075

\begin{abstract}
The present study examined the anti-proliferative effects of piplartine on the human prostate cancer cell line PC-3. This is the first report demonstrating the piplartine anti-cancer activity toward prostate cancer cell lines, although its precise mechanism of action is still not completely defined. In MTT assays, it preferentially inhibited growth of androgenindependent PC-3 cells in a dose-dependent (3-30 $\mu \mathrm{M})$ and time-dependent (12-48 h) manner. In PC-3 cells, it showed an $\mathrm{IC}_{50}$ of $15 \mu \mathrm{M}$ after $24 \mathrm{~h}$ of treatment. After a $24-30 \mu \mathrm{M}$ treatment for $24 \mathrm{~h}$, there were some reduction of cell volume, cell vacuolization, chromatin condensation and increased number of apoptotic cells visible by light and fluorescence microscopy. Agarose gel electrophoresis revealed that cells treated with piplartine exhibited DNA fragmentation. In addition, growth inhibition of PC-3 cells was associated with G2/M arrest and sub-G1 accumulation. Higher concentrations (24-30 $\mu \mathrm{M})$ of piplartine modulated apoptosis-related protein expression by down-regulating cdc- 2 expression and up-regulating PARP/procaspase-3 cleavage. Also, PC-3 cells treated with piplartine demonstrated caspase- 3 activation, as observed with an in vitro caspase- 3 colorimetric assay kit. Taken together, these results demonstrated that high concentrations of piplartine exhibited anti-proliferative and anti-cancer effects on PC-3 cells and that caspase-3-mediated PARP cleavage and cell cycle arrest at $\mathrm{G} 2 / \mathrm{M}$ phase are involved in the underlying cellular mechanism of the apoptosis process.
\end{abstract}

Correspondence to: Dr Soon-Cheol Ahn, Department of Microbiology and Immunology, Pusan National University School of Medicine, Busan 602-739, Korea

E-mail: ahnsc@pusan.ac.kr

${ }^{*}$ Contributed equally

Key words: piplartine, prostate cancer cells, apoptosis, caspase-3, cell cycle

\section{Introduction}

Prostate cancer is the second leading cause of cancer-related death among men in the United States and many other Western countries (1). In the United States alone, one out of nine men over the age of 65 is diagnosed with prostate cancer. Potentially therapeutic options for treating localized prostate cancer include surgical prostatectomy, radiotherapy and hormonal therapy $(2,3)$. But the patient prognosis is poor once the disease becomes metastatic. Prostate carcinogenesis is a multistep process involving progression from localized, low-grade lesions to large, high-grade, metastatic carcinomas. The molecular mechanism underlying the onset or progression of prostate cancer is not fully defined, but age, race, diet, androgen secretion and metabolism have all been identified as risk factors for developing this malignancy. On a molecular level, many of the changes associated with human prostate carcinogenesis involve proteins or pathways that play key roles in apoptosis regulation. Apoptosis is a distinct mode of cell death that deletes cells in malignant tumors as well as normal tissue $(4,5)$, and in the prostate gland, androgen withdrawal promotes apoptotic cellular signals (6).

The poor prognosis in malignant prostate cancer underscores the urgent need to identify alternative chemotherapeutic strategies and develop new combating ways. One approach that is becoming increasingly appreciated in managing neoplasia is chemoprevention, administering agents to suppress, reverse or delay the process of carcinogenesis. Chemopreventive agents can be synthetic or natural compounds; in fact, several naturally-occurring antioxidants are currently being evaluated for chemoprevention of prostate cancer in cultured cells and animal model systems. Some of these agents are even showing promise in human prostate cancer patients. Since the incidence of prostate cancer is so high, clinically developing agents that are non-toxic to normal cells but delay the onset and/or progression of human prostate cancer could significantly ameliorate disease-related cost, morbidity and mortality for a large segment of the population. In the current literature, many natural products have been reported as chemopreventives and clinical usage against several common cancer types. Many of natural 


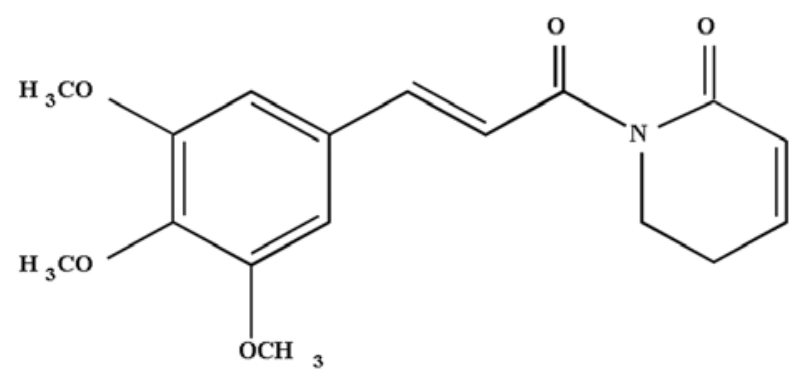

Figure 1. Chemical structure of piplartine (piperlongumine), found within Piper species.

products or their derivatives comprise about $50 \%$ of the current cancer chemotherapy arsenal (7). These have been discovered through routine examination of terrestrial plants and microorganisms, indicating that serendipity is still an important route of discovery (8).

Most of the current cytotoxic anti-cancer drugs act by inducing apoptosis in cancer cells $(6,9)$. Apoptosis is one of the major mechanisms for targeted therapy against various cancers including prostate cancer $(6,9-11)$ but in advanced prostate cancer, cells become resistant to apoptosis and do not respond to cytotoxic chemotherapeutic agents (12). Therefore, compounds that induce apoptotic death of hormonerefractory prostate cancer cells, such as the PC-3 cell line, could be useful in controlling this malignancy at later stages (13-15).

Piper species are used as spices and traditional medicine by many people in Asia and the Pacific islands; they are especially prevalent in Indian medicine. Preparations of Piper species have exhibited anti-inflammatory, anti-feedant, insecticidal and anti-hypertensive activities. They also inhibit aflatoxin B DNA binding, anti-proliferative activity and anticancer activity $(7,16,17)$. In particular, they are useful against asthma, bronchitis, fever, hemorrhoidal afflictions, gastrointestinal diseases and rheumatism (7). Many investigators have revealed that phytochemicals isolated from spices such as these pepper species are potent biological agents with interesting anti-cancer properties (16,17). Piper species contain pyrones, lignoids and chromenes, in addition to various isobutyl-bearing amides, pyrrolidine, dihydropyridone and piperidine moieties (17). These amides have generated interest as a result of their potent cytotoxic activity.

Piplartine (piperlongumine) is an alkaloid/amide component of several Piper species, and in other studies it displayed significant cytotoxic activity against tumor cell lines, as well as anti-fungal and anti-platelet aggregation properties (Fig. 1) (18-20). Compared to some other piperine derivatives, piplartine has not been thoroughly studied, but it is reportedly a more potent anti-mitotic agent in cultured tumor cells (16). The present study is to characterize the effect of piplartine on proliferation of two human prostate cancer cell lines, PC-3 cells and LNCaP cells, and investigate the apoptotic mechanisms underlying its activity.

\section{Materials and methods}

Chemicals. All chemicals used were obtained commercially. Piplartine \{5,6-dihydro-1-[1-oxo-3-(3,4,5-trimethoxyphenyl)-
2-propenyl]-2-(1H)-pyridinone $3\left(\mathrm{C}_{17} \mathrm{H}_{19} \mathrm{NO}_{5}, \mathrm{MW} 317.3\right)$ was purchased from Sigma Chemical Co. (St. Louis, MO, USA) and dissolved in methanol $(\mathrm{MeOH})$. It was diluted in fresh cell medium to the desired concentration just before use. Dihydrotestosterone (DHT), 3-(4,5-dimethyl-thiazol-2-yl)2,5-diphenyl-tetrazolium bromide (MTT), propidium iodide (PI) and 4',6-diamidino-2-phenylindole dihydrochloride (DAPI) were also purchased from Sigma Chemical Co. Mouse $\beta$-actin monoclonal antibody (sc-8432), rabbit bax polyclonal antibody, mouse anti-bcl-2, mouse anti-cdc-2, mouse anti-cyclin B1 (V152), anti-PARP and anti-caspase-3 were purchased from Cell Signaling (Beverly, MA, USA) and Sigma Chemical Co. The ECL Western blotting kit and Immobilon-P were purchased from Amersham (Arlington Heights, IL, USA).

Cell lines and cell culture. Human prostate carcinoma PC-3 cells and LNCaP cells were obtained from the American Type Culture Collection (ATCC, Manassas, VA, USA). PC-3 cells and LNCaP cells were maintained in Dulbecco's modification of essential medium (DMEM; Hyclone Co.; Logan, UT, USA) and RPMI-1640 medium (Hyclone), respectively, both of which were supplemented with $10 \%$ fetal bovine serum (FBS; Hyclone), 100 units/Ml of penicillin and $100 \mu \mathrm{g} / \mathrm{Ml}$ of streptomycin (Hyclone). Cells were cultured at $37^{\circ} \mathrm{C}$ in a humidified atmosphere with $5 \% \mathrm{CO}_{2}$. The cells were diluted and seeded in complete medium one day before each experiment.

MTT cell viability assay. The in vitro cytotoxicity of piplartine on prostate cancer PC-3 cells and $\mathrm{LNCaP}$ cells was measured with an MTT assay, as described $(21,22)$. Briefly, cultured prostate carcinoma PC-3 cells and LNCaP cells were harvested, counted and plated $\left(1 \times 10^{4}\right.$ cells/well $)$ in a 48 well microtiter plate. After a 24-h incubation to allow for attachment, various concentrations of piplartine were added to each well in duplicate. After the indicated incubation times, the medium was removed and $250 \mu 1$ of MTT solution $(0.5 \mu \mathrm{g} / \mathrm{Ml}$ in phosphate-buffered saline) was added to each well for $4 \mathrm{~h}$. Subsequently, $250 \mu \mathrm{l}$ of dimethyl sulfoxide (DMSO) was added to solubilize the MTT-formazan complex, and the plate was analyzed on a microtiter plate reader (Molecular Devices; Sunnyvale, CA, USA) at $540 \mathrm{~nm}$ to determine the concentration demonstrating $50 \%$ cytotoxicity on the tumor cells $\left(\mathrm{IC}_{50}\right.$ value).

Cytomorphology. Exponentially-growing cells were seeded $\left(1 \times 10^{5}\right.$ cells/well $)$ in $24-w e l l$ plates $(22,23)$. After attachment, the cells were incubated in the absence or presence of piplartine at various concentrations for different time intervals. The cells were then rinsed with phosphate-buffered saline (PBS), fixed in $4 \%$ formaldehyde, and stained with $1 \mu \mathrm{g} /$ Ml DAPI for $30 \mathrm{~min}$. Stained nuclei were visualized under UV excitation and photographed using a Leica DMRB microscope (Leica Microsystems Holdings GmbH; Germany). Hoechst 33258 staining was used to observe the apoptotic morphology of the cells. Cells were fixed with 4\% formaldehyde in PBS for 10 min, stained with Hoechst $33258(10 \mu \mathrm{g} / \mu \mathrm{l})$ for $1 \mathrm{~h}$, and observed by fluorescence microscopy. 
Flow cytometric analysis. The cell cycle progression of PC-3 cells following piplartine treatment was analyzed by flow cytometry as described elsewhere $(21,24)$. Briefly, cells were fixed with $70 \%$ ethanol at $-20^{\circ} \mathrm{C}$ for at least $12 \mathrm{~h}$. After two washes with PBS, the cells were incubated in $100 \mu 1 \mathrm{RNase} \mathrm{A} /$ PBS $(200 \mu \mathrm{g} / \mathrm{Ml})$ at $37^{\circ} \mathrm{C}$ for $30 \mathrm{~min}$. Intracellular DNA was labeled with $100 \mu \mathrm{l} \mathrm{PI}(1 \mathrm{mg} / \mu \mathrm{l})$ at $4^{\circ} \mathrm{C}$ for $5 \mathrm{~min}$, and the stained cells were analyzed by flow cytometry for relative DNA content (based on increased red fluorescence) with a FACScalibur flow cytometer (Becton-Dickinson Co.; Franklin Lakes, NJ, USA). Data collection and analysis of cell cycle distribution were performed using CellQuest and Modfit software (Becton-Dickinson Co.).

DNA fragmentation assay. Apoptotic DNA fragmentation induced in PC-3 cells after piplartine treatment was determined as previously described $(21,22,24)$. Briefly, untreated and piplartine-treated PC-3 cells were harvested by scraping and centrifugation, washed with PBS, and resuspended in $100 \mu 1$ of lysis buffer [10 mM Tris- $\mathrm{HCl}$ ( $\mathrm{pH} 7.4), 10 \mathrm{mM}$ EDTA ( $\mathrm{pH} 8.0), 0.5 \%$ Triton $\mathrm{X}-100]$ for $20 \mathrm{~min}$ on ice. Lysates were centrifuged at $14,000 \mathrm{x}$ g for $10 \mathrm{~min}$ on ice, and the resulting supernatants were incubated with RNase A (200 $\mu \mathrm{g} / \mathrm{Ml})$ at $37^{\circ} \mathrm{C}$ for $60 \mathrm{~min}$ and proteinase $\mathrm{K}(200 \mu \mathrm{g} / \mathrm{Ml})$ at $50^{\circ} \mathrm{C}$ for $30 \mathrm{~min}$ to remove RNA and protein, respectively. Following precipitation with $20 \mu \mathrm{l}$ of $5 \mathrm{M} \mathrm{NaCl}$ and $120 \mu \mathrm{l}$ of isopropanol at $-20^{\circ} \mathrm{C}$ for $12 \mathrm{~h}$, the precipitated DNA pellet was dissolved in Tris-acetate EDTA buffer and analyzed by electrophoresis at $60 \mathrm{~V}$ for $3 \mathrm{~h}$ in a $1.5 \%$ agarose gel. The DNA present in the gel was stained with ethidium bromide (EtBr) and visualized under UV light.

Western blot analysis. Cells $\left(1 \times 10^{6}\right.$ or $\left.5 \times 10^{5}\right)$ were seeded in 6-well plates. After $24 \mathrm{~h}$, the cells were incubated with vehicle or various concentrations of piplartine for the indicated times, as described previously $(23,25)$. Cells were washed with ice-cold PBS, lysed in lysis buffer [150 mM NaCl, $10 \mathrm{mM}$ Tris (pH 7.4), 5 mM EDTA (pH 8.0), 1\% Triton X-100, 1 mM PMSF, $20 \mathrm{mg} / \mathrm{Ml}$ aprotinin, $50 \mu \mathrm{g} / \mathrm{Ml}$ leupeptin, $1 \mathrm{mM}$ benzaidine, $1 \mathrm{mg} / \mathrm{Ml}$ pepstatin], and centrifuged (15,000 x g, $30 \mathrm{~min}, 4^{\circ} \mathrm{C}$ ). Total protein concentration was determined by the BCA method. Equal amounts of protein $(40 \mu \mathrm{g})$ in the cell extracts were fractionated by $12 \%$ SDS-PAGE denaturing gels and transferred to PVDF membranes. The membranes were blocked in $20 \mathrm{mM}$ Tris-buffered saline- $0.1 \%$ Tween-20 (TBST) buffer containing 5\% skim-milk at room temperature (RT) for $2 \mathrm{~h}$ and probed with specific primary antibodies overnight at $4^{\circ} \mathrm{C}$. After washing with TBST for $1 \mathrm{~h}$, the membranes were incubated with horseradish peroxidase (HRP)-conjugated anti-rabbit/mouse IgG for $50 \mathrm{~min}$ at RT and washed with TBST for $40 \mathrm{~min}$. Immunoreactive proteins were visualized using an ECL Western blotting detection reagent (Amersham). Band densities were determined with a fluorescence scanner (LAS3000; Fuji Film; Tokyo, Japan) and analyzed with Multi Gauge V3.0 software.

In vitro caspase-3 activity assay. In vitro caspase-3 activity in piplartine-treated PC-3 cells was monitored using a caspase-3 colorimetric assay kit (R\&D Systems, Inc.; Minneapolis, MN, USA) based on the cleavage of Asp-Glu-
Val-Asp (DEVD)-pNA.25 Briefly, cells $\left(2 \times 10^{6}\right.$ cells/Ml $)$ were lysed on ice for $10 \mathrm{~min}$ and centrifuged at $10,000 \mathrm{x} \mathrm{g}$ for $1 \mathrm{~min}$. Enzyme reactions were carried out on the resulting supernatants in 96-well flat-bottom microplates, using $50 \mu \mathrm{l}$ of cell lysate (100-200 $\mu \mathrm{g}$ of total protein) for each reaction mixture. The results were expressed as specific activities (UI/mg protein) of caspase-3.

Statistical analysis. The statistical significance of the differences between control and experimental groups was evaluated for pairs of parallel experiments using Student's t-test. All experiments were conducted in duplicate, and standard deviations are indicated in the figures with error bars.

\section{Results}

Piplartine suppressed the growth of human prostate cancer cells. To determine the extent to which piplartine inhibited cell growth of human prostate carcinomas, we exposed two prostate cancer cell lines to different concentrations of piplartine for different times and measured the resulting cell viability with MTT assays. The results are expressed as relative cell viabilities compared to untreated cells (percent of control). Since androgen withdrawal induces apoptosis in prostate cells, we compared responses between an androgenindependent (PC-3) and an androgen-dependent (LNCaP) cell line. Piplartine treatment for 24,36 and $48 \mathrm{~h}$ significantly inhibited PC-3 cell growth in a dose-dependent manner (12-18 $\mu \mathrm{M})$, indicating its ability to impair proliferation potential (Fig. 2A). Piplartine reduced PC-3 cell numbers with an $\mathrm{IC}_{50}$ of $15 \mu \mathrm{M}$ after $24 \mathrm{~h}$ of treatment (Fig. $2 \mathrm{C}$ ). In contrast, piplartine-mediated growth inhibition was weak or undetectable in the androgen-dependent LNCaP cells regardless of whether androgen was present (Fig. 2B), which mean remarkable resistance to piplartine. These results indicated that piplartine more effectively inhibited proliferation of androgen-independent PC-3 cells than androgen-dependent LNCaP cells, with or without DHT.

Morphological changes accompanied piplartine treatment. Morphological comparison of piplartine-treated and untreated PC-3 cells revealed severe drug-mediated changes. The piplartine-mediated decrease in cell viability resulted from cell shrinkage, as observed under phase contrast microscopy (Fig. 3), which could indicate apoptotic cell death. Untreated PC-3 cells exhibited normal features after $24 \mathrm{~h}$ of culture, with typical adherent, homogeneous, and spanning morphology. Following exposure to 3-30 $\mu \mathrm{M}$ piplartine for $24 \mathrm{~h}$, the majority of PC-3 cells developed a non-adherent, detached, and rounded morphology, with dose-dependent prevalence and severity. In addition, the piplartine-treated cells were somewhat larger than control cells, in both cellular size and cytoplasmic content.

In order to further examine morphological changes in response to piplartine treatment, we stained control and piplartine-treated PC-3 cells with fluorescent dyes (DAPI or Hoechst 33258) and visualized them under a fluorescence microscope. The control cells appeared normal, with round and homogeneous nuclei, while the piplartine-treated cells 
(A)

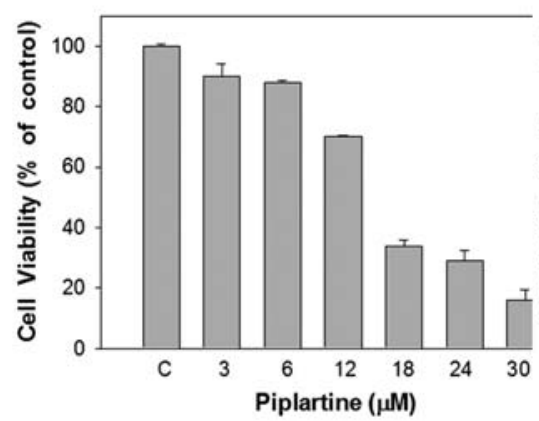

(B)

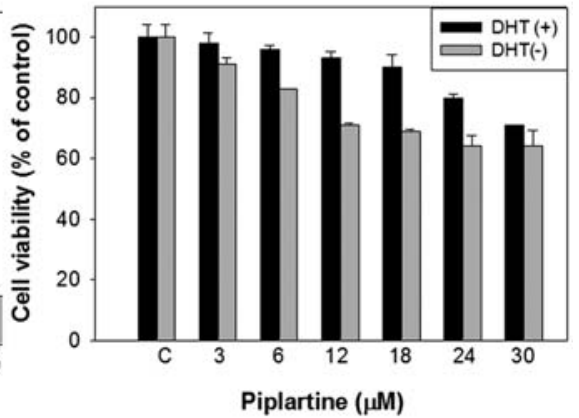

(C)

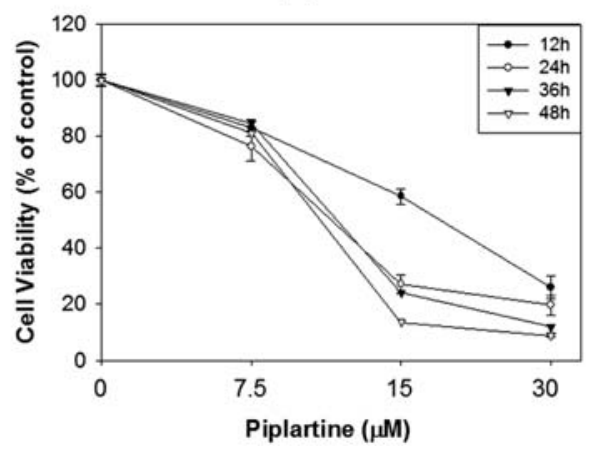

Figure 2. Growth inhibition of piplartine in PC-3 cells and LNCaP cells. The effect of piplartine on the viability of PC-3 cancer cells was determined using MTT assays. (A) PC-3 cells and (B) LNCaP cells were exposed to piplartine (3, 6, 12, 18, 24 or $30 \mu \mathrm{M})$ for $24 \mathrm{~h}$. (C) PC-3 cells were exposed to $7.5,15$ or $30 \mu \mathrm{M}$ piplartine for $12,24,36$ or $48 \mathrm{~h}$
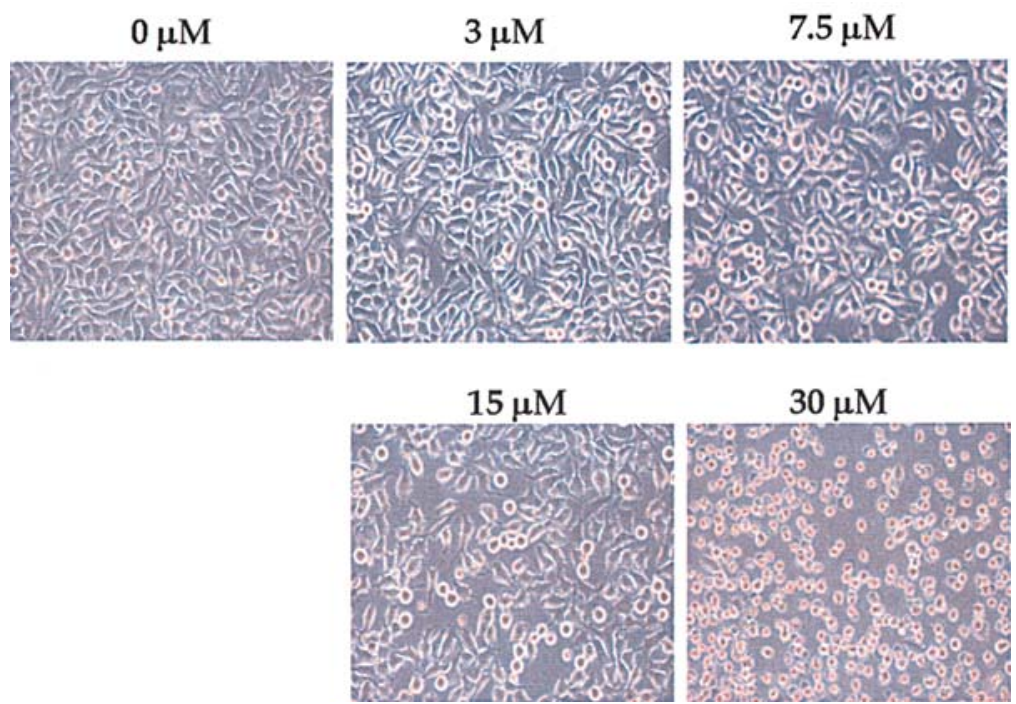

Figure 3. Morphological changes induced by piplartine in PC-3 cells. Human prostate PC-3 cells, untreated or treated with piplartine at different concentrations, were analyzed by phase contrast microscopy. Non-adherent, detached and rounded PC-3 cell morphologies are shown.

exhibited the characteristic features of apoptosis, as indicated by DAPI staining (Fig. 4A). At $18 \mu \mathrm{M}$ and $30 \mu \mathrm{M}$, piplartine caused cell shrinkage, vacuolization, chromatin condensation, nuclei DNA fragmentation and pyknotic nuclei, all of which indicated an increasing number of dead cells and suggested apoptosis. Furthermore, Hoechst-stained cells that had been treated with $30 \mu \mathrm{M}$ piplartine for $24 \mathrm{~h}$ exhibited typical apoptosis morphology: volume reduction, chromatin conden- sation, nuclear fragmentation and appearance of apoptotic bodies (Fig. 4B). These morphological observations suggested that piplartine might reduce overall $\mathrm{PC}-3$ cell numbers by inducing apoptosis.

Piplartine caused nucleosomal DNA fragmentation in PC-3 cells. An important feature of apoptosis is the fragmentation of genomic DNA into integer multiples of 180-bp units, 


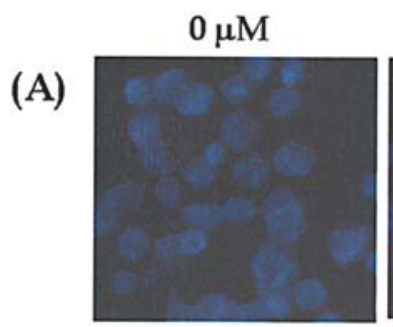

$18 \mu \mathrm{M}$
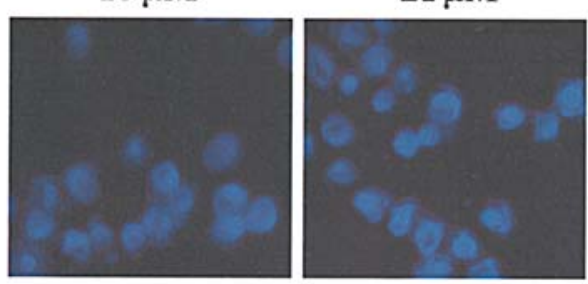

$6 \mu \mathrm{M}$

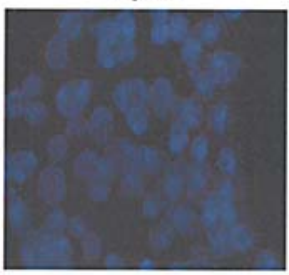

$24 \mu \mathrm{M}$

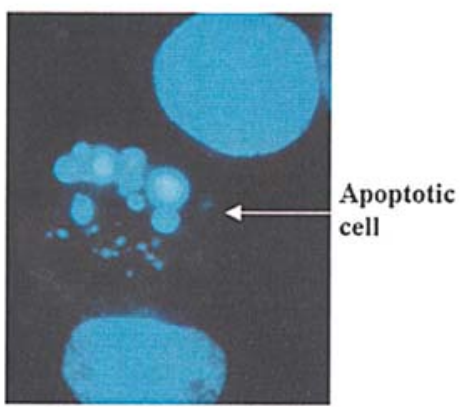

$12 \mu \mathrm{M}$

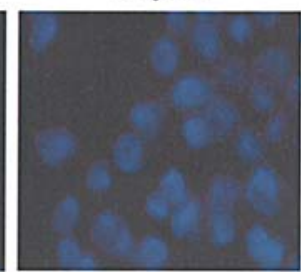

$30 \mu \mathrm{M}$

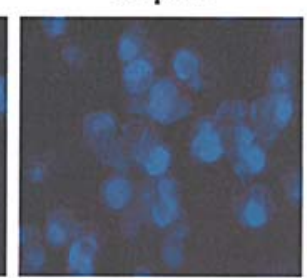

(B)

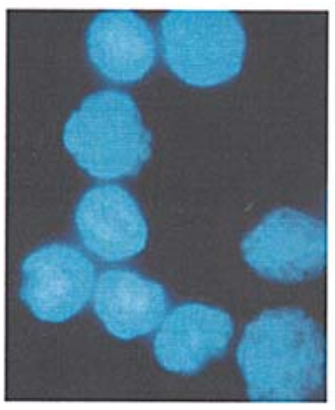

Figure 4. Apoptotic morphological changes induced by piplartine in PC-3 cells. (A) Human prostate PC-3 cells were untreated or treated with piplartine at different concentrations. Apoptotic cells were detected by fluorescence microscopy (x400) based on nuclear morphology changes after DAPI staining. Pyknotic nuclei, chromatin condensation, and nuclear fragmentation induced by high concentrations of piplartineare shown. (B) PC-3 cells were treated with $30 \mu \mathrm{M}$ piplartine for $24 \mathrm{~h}$; magnified treated cells displayed pyknotic nuclei, chromatin condensation and nuclear fragmentation under fluorescence microscopy after Hoechst 33258 staining.

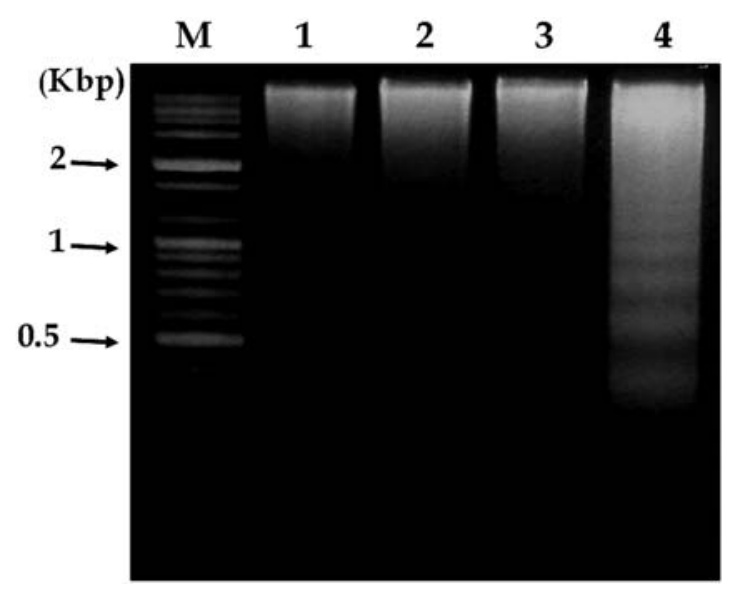

Figure 5. DNA fragmentation in piplartine-treated PC-3 cells. Equivalent amounts of DNA were subjected to electrophoresis on a $1.5 \%$ agarose gel $(100 \mathrm{~V}$ for $30 \mathrm{~min}$ ) at room temperature, and DNA fragmentation was visualized by EtBr staining. Piplartine induced apoptosis of PC-3 cells in a dose-dependent manner. PC-3 cells were untreated (lane 1) or treated with $7.5 \mu \mathrm{M}$ (lane 2), $15 \mu \mathrm{M}$ (lane 3) or $30 \mu \mathrm{M}$ piplartine (lane 4).

resulting in a characteristic ladder on agarose gel electrophoresis. We therefore utilized agarose gel electrophoresis to examine piplartine-treated cells for DNA fragmentation, in order to directly detect apoptosis. The DNA from PC-3 cells showed typical DNA fragmentation when cells were treated with different concentrations of piplartine for $24 \mathrm{~h}$ (Fig. 5), demonstrating that piplartine treatment mediates PC-3 cell apoptosis.

Piplartine induced cell cycle arrest at G2/M phase in PC-3 cells. Using flow cytometry, we also examined the cell cycle distribution of cells that had been treated with various doses of piplartine. As shown in Fig. 6, 24-h treatments with different concentrations of piplartine arrested a significant proportion of the cells in $\mathrm{G} 2 / \mathrm{M}$ phase. At $24 \mu \mathrm{M}$, piplartine induced the most significant increase in the $\mathrm{G} 2 / \mathrm{M}$ cell population. In cells that had been exposed to 30 or $45 \mu \mathrm{M}$ piplartine, this procedure yielded a dramatic hypodiploid (sub-G1) population in PC-3 cells. Moreover, in cells that had been treated with 24-30 $\mu \mathrm{M}$, the decrease in polyploid cells was associated with a reciprocal increase in the sub-G1 cell population, indicating that the arrested PC-3 cells entered into apoptosis

Piplartine regulated the expression of $c d c-2$ and cyclin $B 1$ in $P C-3$ cells. Our data thus far implied that piplartine inhibited PC-3 growth by initiating a G2/M phase cell cycle block and inducing apoptosis. We therefore examined expression levels of target molecules related to cell cycle progression, specifically cyclin B1 and cdc-2, because they are critical for G2/M transition. In these experiments, we treated PC-3 cells with piplartine at different concentrations $(0,3,7.5,15,30 \mu \mathrm{M})$ for $24 \mathrm{~h}$, and we subjected their whole cell lysates to Western 
(A)
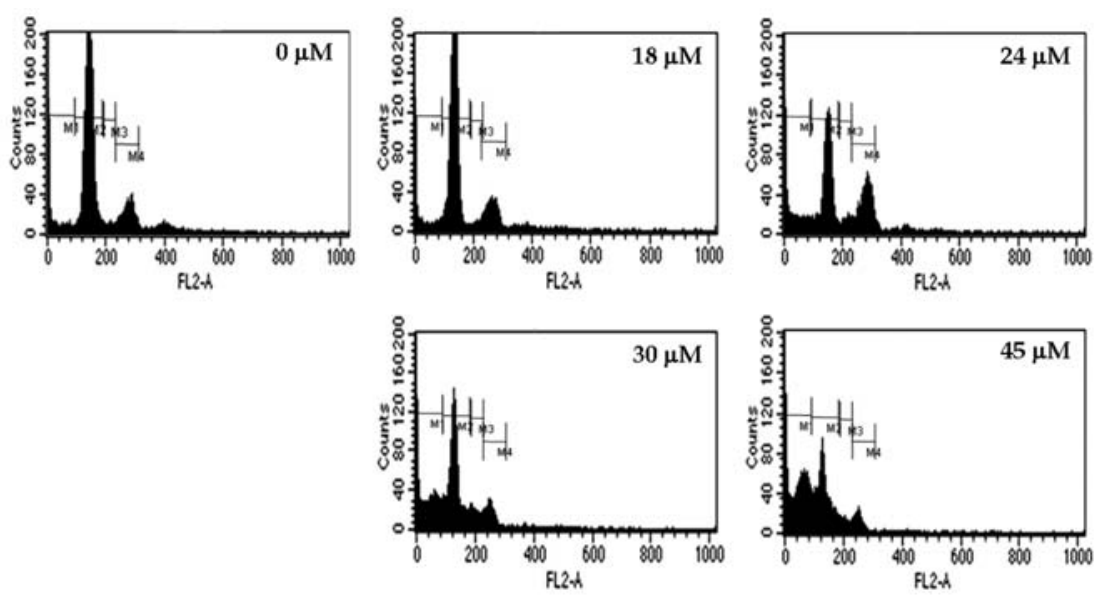

(B)

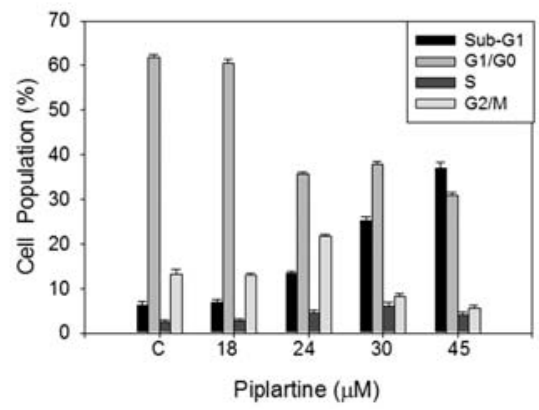

Figure 6. Effect of piplartine on cell cycle distribution in PC-3 cells. (A) Intracellular DNA content was analyzed with PI staining, and cell cycle arrest analysis was quantified following flow cytometry. PC-3 cells were seeded at $1 \times 10^{4}$ cells/well in 6-well plates and exposed to different concentrations of piplartine for $24 \mathrm{~h}$. The cells were harvested, washed, fixed with ice-cold 70\% (v/v) ethanol, and stained with PI (1 mg/Ml). (B) PC-3 cells were untreated or treated with piplartine at different concentrations, and cell cycle distribution was analyzed and graphed.

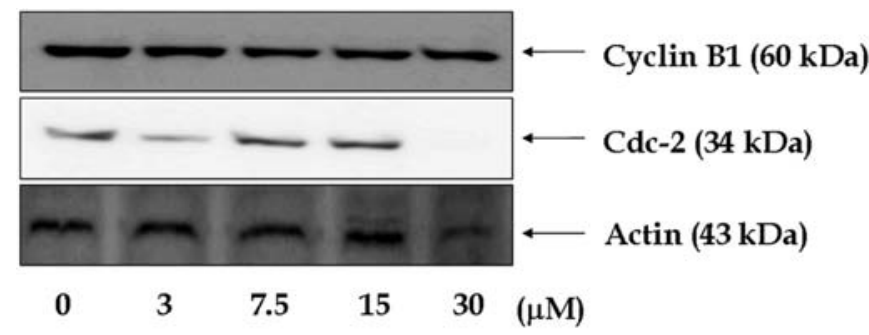

Figure 7. Effects of piplartine on expression of cyclin B1 and cdc-2 in PC-3 cells. Total cell lysates from PC-3 cells treated for $24 \mathrm{~h}$ with various concentrations of piplartine were separated by $15 \%$ PAGE and immunoblotted with the antibodies indicated; B-actin served as the internal control.

blot analysis (Fig. 7). Compared to the B-actin control, $30 \mu \mathrm{M}$ piplartine decreased the levels of cdc-2, which correlated with the G2/M phase cell cycle arrest. In contrast, expression of cyclin B1 was not altered significantly at that concentration of piplartine. These observations suggested a role for cdc-2 in the mechanism underlying piplartine-mediated cell cycle arrest.

Piplartine regulated the expression of bcl-2 family in PC-3 cells. To gain insights into the mechanism underlying piplartine-induced apoptosis, we used immunoblotting to determine the effect of piplartine treatment on levels of bcl-2 family proteins. The bcl-2 family proteins regulate apoptosis by functioning as activators (e.g., bax and bak) or inhibitors

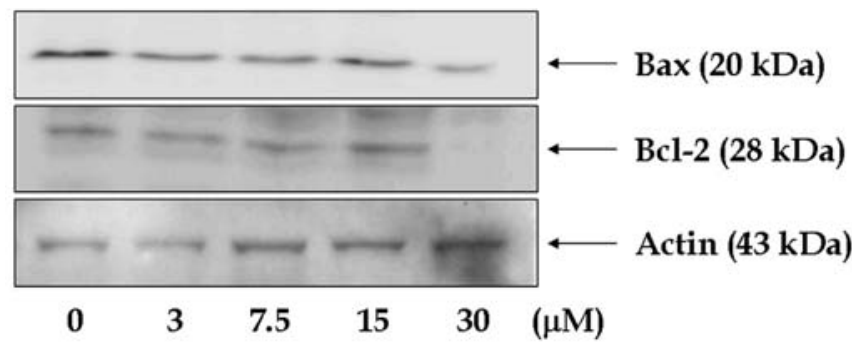

Figure 8. Effects of piplartine on expression of bcl-2 and bax in PC-3 cells. Total cell lysates from PC-3 cells treated for $24 \mathrm{~h}$ with various concentrations of piplartine were separated by $15 \%$ PAGE and immunoblotted with the antibodies indicated. ß-actin served as the internal control.

(e.g., bcl-2 and bcl-xL) of the cell death process. As shown in Fig. 8, piplartine treatment did not significantly alter levels of bax protein, but we did observe a piplartine-mediated decrease in expression of the anti-apoptotic protein bcl-2; bcl-2 protein levels declined below control levels in cells treated with $30 \mu \mathrm{M}$ piplartine. These results suggested that piplartine-induced cell death might be regulated by bcl-2 family proteins.

Piplartine regulated the expression of caspase-3 and PARP in $P C-3$ cells. To further unravel the apoptotic mechanism underlying piplartine-induced apoptosis, we examined whether piplartine affected activation of caspase- 3 and poly(ADPribose) polymerase, two effector proteins that are activated 


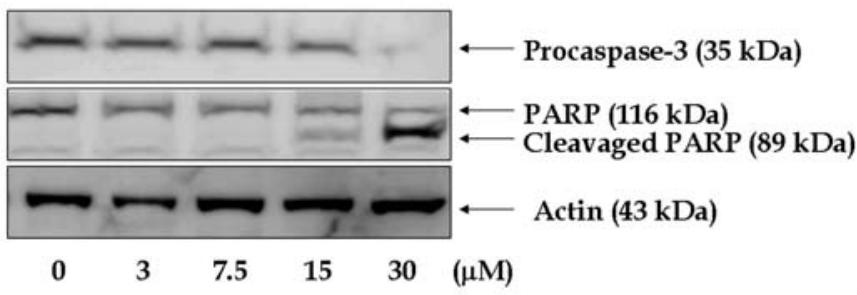

Figure 9. Effects of piplartine on cleavage of PARP and procaspase- 3 in PC-3 cells. Total cell lysates from PC-3 cells treated for $24 \mathrm{~h}$ with various concentrations of piplartine were separated by $12 \%$ PAGE and immunoblotted with the antibodies indicated. B-actin served as the internal control.

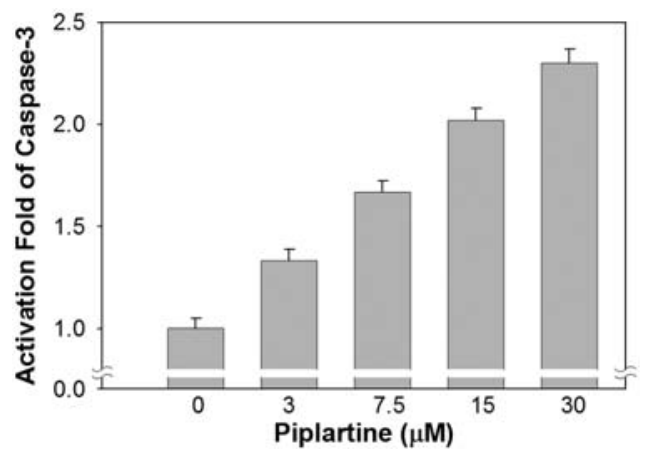

Figure 10 . Caspase- 3 activity induced by piplartine in PC-3 cells. A caspase- 3 colorimetric assay kit was used to investigate caspase- 3 activity in piplartinetreated PC-3 cells, based on the cleavage of Asp-Glu-Val-Asp (DEVD)-pNA. Enzyme reactions on cell lysates (100-200 $\mu \mathrm{g}$ of total protein) were carried out in 96-well flat-bottom microplates. The results are expressed as specific activity (U1/mg protein) of caspase-3.

by proteolytic cleavage during the final stages of apoptosis. Once cells have released cytochrome $\mathrm{c}$ from the mitochondria to the cytosol, it binds to Apaf-1, which activates procaspase-9 after recruiting it to the apoptosome. Active caspase- 9 cleaves and activates executer caspases, including caspase-3, which subsequently cleave a broad spectrum of cellular target proteins, including poly-(ADP-ribose) polymerase, during induction of cell death. Treatment of PC-3 cells with piplartine $(0,3,7.5,15,30 \mu \mathrm{M})$ for $24 \mathrm{~h}$ significantly increased the cleavage of procaspase- 3 and poly-(ADP-ribose) polymerase compared to untreated cells (Fig. 9). B-actin was analyzed as a loading control.

To confirm the role of caspase- 3 activation in piplartineinduced apoptosis, we employed a colorimetric caspase-3 activity assay (Fig. 10). Treatment of PC-3 cells with piplartine for $24 \mathrm{~h}$ resulted in a dose-dependent increase in caspase- 3 activity, suggesting that piplartine mediated PC-3 apoptosis through enhancing the activity of caspase- 3 .

\section{Discussion}

In this study, we conducted an unprecedented investigation of how piplartine, an alkaloid/amide found in Piper species, acts against human prostate cell lines. We also examined for the first time the underlying mechanisms of anti-cancer properties of piplartine. We investigated the effects of piplartine on cell viability and proliferation of two prostate cancer cell lines, androgen-independent PC-3 and androgendependent $\mathrm{LNCaP}$, and we demonstrated that piplartine mediates dose- and time-dependent cytotoxic and antiproliferative effects that were most pronounced in the androgen-independent PC-3 cell line. Previous reports demonstrated that piplartine is cytotoxic to several tumor cell lines $(19,26)$, and our result indicated that piplartine is equally effective on PC-3 cells, but exactly how piplartine mediated these effects had not been examined prior to this study. This informational gap prompted us to further study the molecular mechanism behind piplartine activity in prostate cancer cells.

We detected all of the major apoptotic events in piplartinetreated $\mathrm{PC}-3$ cells, but our results revealed that piplartine preferentially inhibited growth in PC-3 cells as well, in which piplartine was mainly associated with the induction of apoptosis. Piplartine-induced apoptosis was confirmed in multiple approaches: nuclear morphologic changes, DNA fragmentation and flow cytometric analysis. The morphological definition of apoptosis and necrosis is based on membrane integrity (27). Morphological observations showed that piplartine-treated cells were easily discerned from untreated cells (their rounded shapes were quite distinct from the polygonal shapes of untreated cells), suggesting that piplartine might induce both growth arrest and apoptosis. These morphological alterations and induction of apoptosis could be due to piplartine cytotoxicity. The apoptosis evoked by piplartine was also confirmed by changes in nuclear morphology and chromosomal DNA fragmentation. In addition to confirming induction of apoptosis, the present study clearly demonstrated that piplartine initiated a series of events leading to G2/M arrest in PC-3 cells. Flow cytometric analysis showed that PC-3 cells treated with different concentrations of piplartine for $24 \mathrm{~h}$ predominantly accumulated in the G2/M phase of the cell cycle; arrest was exacerbated by higher doses of piplartine. Cells subsequently accumulated in the sub-G1 phase of cell cycle, suggesting that piplartine mediated sequential cell cycle arrest and apoptosis.

The cyclin/cdk complexes are the cell cycle regulators that mediate cell cycle progression. Our observation of functional p53-deficient PC-3 cells conflicts with the report that $\mathrm{p} 53$ arrests cell cycle at $\mathrm{G} 2 / \mathrm{M}$ phase. In the present study, however, piplartine arrests $\mathrm{PC}-3$ cells in G2/M phase, suggesting that piplartine might exert its effects by modulating the cyclin B1/cdc-2 complex. Western blots revealed a dosedependent decrease of cdc-2 expression and activation of procaspase- 3 and PARP cleavage in the piplartine-treated PC-3 cells. These observations suggested that piplartine arrested the cells at the G2/M phase by indirectly inactivating cdc-2, which prevented them from entering mitosis. In PC-3 cells treated with piplartine, changes in levels of bax were undetectable, but bcl-2 decreased significantly, suggesting that piplartine induced apoptosis through down-regulation of bcl-2. Piplartine treatment also enhanced caspase-3-mediated PARP cleavage, suggesting that this pathway is involved in the PC-3 apoptosis process induced by piplartine.

Taken together, our data implied that piplartine-mediated growth inhibition is related to the $\mathrm{G} 2 / \mathrm{M}$ phase cell cycle arrest associated with the down-regulation of cdc-2, and its induction of apoptosis is associated with up-regulation of procaspase- 3 cleavage and PARP cleavage. Piplartine showed 
dose- and time-dependent cytotoxic and anti-proliferative effects in prostate cancer cells, and these effects seem to be selective for tumor cells, especially the androgen-refractory PC-3 cells. These results provide a molecular basis for how these potent lead inhibitors act as anti-tumor agents in chemotherapy for human prostate cancer. This study also presents piplartine as a promising lead candidate compound with which to explore the anti-cancer drug potential of Piper compounds.

\section{Acknowledgements}

This study was supported by Medical Research Institute Grant (2008-28-00), Pusan National University.

\section{References}

1. Jemal A, Murray T, Ward E, Samuels A, Tiwari RC, Ghafoor A, Feuer EJ and Thun MJ: Cancer statistics, 2005. CA Cancer J Clin 55: 10-30, 2005.

2. Swanson GP, Riggs $M$ and Earle J: Failure after primary radiation or surgery for prostate cancer; differences in response to androgen ablation. J Urol 172: 525-528, 2004.

3. Swanson GP: Management of locally advanced prostate cancer: past, present, future. J Urol 176: S34-S41, 2006.

4. Rossi D and Gaidano G: Messengers of cell death: apoptotic signaling in health and disease. Haematologica 88: 212-218, 2003.

5. Gurumurthy S, Vasudevan KM and Rangnekar VM: Regulation of apoptosis in prostate cancer. Cancer Metastasis Rev 20: 225-243, 2001.

6. Buttyan R, Shabsigh A, Perlman $\mathrm{H}$ and Colombel M: Regulation of apoptosis in the prostate gland by androgenic steroids. Trends Endocrinol Metab 10: 47-54, 1999.

7. Reddy L, Odhav B and Bhoola KD: Natural products for cancer prevention: a global perspective. Pharmacol Ther 99: 1-13, 2003.

8. Mann J: Natural products in cancer chemotherapy: past, present and future. Nat Rev Cancer 2: 143-148, 2002.

9. Lowe SW and Lin AW: Apoptosis in cancer. Carcinogenesis 21: 485-495, 2000.

10. Guseva NV, Taghiyev AF, Rokhlin OW and Cohen MB: Death receptor-induced cell death in prostate cancer. J Cell Biochem 91: 70-99, 2004.

11. Jiang C, Wang Z, Ganther $\mathrm{H}$ and $\mathrm{Lu} \mathrm{J}$ : Caspases as key executors of methyl selenium-induced apoptosis (anoikis) of DU145 prostate cancer cells. Cancer Res 61: 3062-3070, 2001.

12. Pilat MJ, Kamradt JM and Pienta KJ: Hormone resistance in prostate cancer. Cancer Metastasis Rev 17: 373-381, 1998-99.
13. Petrylak DP, Tangen CM, Hussain MH Jr, Lara PN, Jones JA, Taplin ME, Burch PA, Berry D, Moinpour C, Kohli M, Benson MC, Small EJ, Raghavan D and Crawford ED: Docetaxel and estramustine compared with mitoxantrone and prednisone for advanced refractory prostate cancer. N Engl J Med 351: 1513-1520, 2004.

14. Petrylak DP: The current role of chemotherapy in metastatic hormone-refractory prostate cancer. Urology 65: 3-7, 2005.

15. Kantoff PW: New agents in the therapy of hormonerefractory prostate cancer. Semin Oncol 22: 32-34, 1995.

16. Lampe JW: Spicing up a vegetarian diet: chemopreventive effects of phytochemicals. Am J Clin Nutr 78: S579-S583, 2003.

17. Parmar VS, Jain SC, Bisht KS, Jain R, Taneja P, Jha A, Tyagi OM, Prasad AK, Wengel J, Olsen CE and Boll PM: Phytochemistry of the genus Piper. Phytochemistry 46: 597-673, 1997.

18. Tsai IL, Lee FP, Wu CC, Duh CY, Ishikawa T, Chen JJ, Chen YC, Seki $\mathrm{H}$ and Chen IS: New cytotoxic cyclobutanoid amides, a new furanoid lignan and anti-platelet aggregation constituents from Piper arborescens. Planta Medica 71: 535-542, 2005.

19. Duh CY, Wu YC and Wang SK: Cytotoxic pyridone alkaloids from Piper aborescens. Phytochemistry 29: 2689-2691, 1990.

20. Silva RV, Navickiene HMD, Kato MJ, Bolzani VS, Méda CI, Young MCM and Furlan M: Antifungal amides from Piper arboreum and Piper tuberculatum. Phytochemistry 59: 521-527, 2002.

21. Wang G, Chen H, Huang M, Wang N, Zhang J, Zhang Y, Bai G, Fong WF, Yang $\mathrm{M}$ and Yao $\mathrm{X}$ : Methyl protodioscin induces G2/M cell cycle arrest and apoptosis in HepG2 liver cancer cells. Cancer Lett 241: 102-109, 2006.

22. Furre IE, Moller MT, Shahzidi S, Nesland JM and Peng Q: Involvement of both caspase-dependent and -independent pathways in apoptotic induction by hexaminolevulinatemediated photodynamic therapy in human lymphoma cells. Apoptosis 11: 2031-2042, 2006.

23. Perez-Stable C: 2-Methoxyestradiol and paclitaxel have similar effects on the cell cycle and induction of apoptosis in prostate cancer cells. Cancer Lett 231: 49-64, 2006.

24. Huang EJ, Wu CC, Huang HP, Liu JY, Lin CS, Chang YZ, Lin JA, Lin JG, Chen LM, Lee SD, Kuo WW and Huang CY: Apoptotic and anti-proliferative effects of 17 beta-estradiol and 17 beta-estradiol-like compounds in the Hep3B cell line. Mol Cell Biochem 290: 1-7, 2006.

25. Huang YT, Pan SL, Guh JH, Chang YL, Lee FY, Kuo SC and Teng CM: YC-1 suppresses constitutive nuclear factor-kappa B activation and induces apoptosis in human prostate cancer cells. Mol Cancer Ther 4: 1628-1635, 2005.

26. Bezerra DP, Pessoa C, Moraes MO, Silveira ER, Lima MAS, Elmiro FJM and Costa-Lotufo LV: Antiproliferative effects of two amides, piperine and piplartine, from Piper species. Zeitschrift für Naturforschung 60: 539-543, 2005.

27. Masquelier M, Zhou QF, Gruber A and Vitols S: Relationship between daunorubicin concentration and apoptosis induction in leukemic cells. Biochem Pharmacol 67: 1047-1056, 2004. 